Saudi Journal of Business and Management Studies Abbreviated Key Title: Saudi J Bus Manag Stud ISSN 2415-6663 (Print) |ISSN 2415-6671 (Online) Scholars Middle East Publishers, Dubai, United Arab Emirates Journal homepage: http://scholarsmepub.com/sjbms/

Original Research Article

\title{
Airport Service Quality Dimensions and its Influence on Airline Passengers' Satisfaction in India
}

\author{
Dr. Joemon Pappachan* \\ Assistant Professor, CIASL Aviation Academy, Kochi Airport P.O. Nedumbassery, Cochin, India
}

DOI: $10.36348 /$ sjbms.2020.v05i01.002 $\quad$ | Received: 28.12.2019| Accepted: 08.01.2020 | Published: 14.01 .2020

*Corresponding author: Dr. Joemon Pappachan

Abstract

This paper is aiming at the refinement of Airport Service Quality (ASQ) dimensions based on passengers' experience. This new ASQ dimensions evolved are in contrast with the conventional method of setting apart areas concerning ASQ as recognized at every interaction points in the functional flow of passengers through various agencies in the airport. The new dimensions arrived in this study were obtained by analyzing the data regarding airport service quality attributes identified and surveyed with the support of instruments developed by Airports Council International (ACI) and are commonly used by airports in India. This study further analyzed and factorized those items into meaningful ASQ dimensions from passengers' perspective using exploratory factor analysis method and then confirmed the measurement model using confirmatory factor analysis. This study also attempts to find out the relationship between these core dimensional factors of airport service quality and its influence on overall satisfaction of passengers. The interrelationship between these ASQ factors and overall satisfaction level of passengers were estimated using structural equation modeling. The strength of each factor dimension was plotted and drawn implications for the airport operators.

Keywords: Airport Service Quality; Factor Analysis; Passenger Satisfaction; ASQ dimensions; Airport facilities; Structural Equation Modeling.

Copyright @ 2020: This is an open-access article distributed under the terms of the Creative Commons Attribution license which permits unrestricted use, distribution, and reproduction in any medium for non-commercial use (NonCommercial, or CC-BY-NC) provided the original author and source are credited.

\section{INTRODUCTION}

Airport facilities and services play a significant role in the overall satisfaction of passengers travelling through an airport. Though airport service quality parameters have fewer roles in the purchase decision of an airline ticket, the service quality of the airport becomes momentous when the customers are in the airport.

An international airport typically handles air travelers from different countries around the world; different countries possess different types of culture, it is difficult to predict the nature of expectations of passengers and thereby the underlying ASQ dimensions [1]. It is widely accepted that airport service quality is the perception of passengers toward a product or service delivered by the Airport. Service quality can be understood as a consumer's overall impression about the company and its services [2] or it can be said that service quality are those efforts by the companies which include a chain of performances delivered often divided into a series of processes [3]. Airline service quality is composed of many interactions that involves customers and airlines in which employees trying to boost up the image of the airlines and influence passengers perceptions [4].

According to the research report of ACI 2017, passengers consider ticket price, direct flight availability, flight schedule time and brand image of the airline are significant airline related factors. ACI-ASQ customer satisfaction survey being conducted worldwide quarterly which includes 33 questions related to facilities and services offered by an airport. In fact these areas covers major customer contact points or the areas where customer experiences service quality of airports for instance; facilities related to access, checkin at the airports, passport personal id controls, security, way finding, airport facilities, airport environment and 
Joemon Pappachan; Saudi J Bus Manag Stud, Jan., 2020; 5(1): 10-18

arrival facilitation. The customer feedback so obtained would help airports to understand various shortfalls in their service delivery at each customer interaction points and could further improve these facilities. However the underlying dimensions or the factors that ultimately influence the customer satisfaction other than the level of performance at each functional interaction points were not very clearly understood so far or scarcely researched. As defined in an ASQ survey, an increase in one percent in the global passenger satisfaction would result in generating an average growth of non-aeronautical revenue by 1.5 per cent.

Bogicevic et al., [5], studied about the satisfiers and dissatisfiers of airport service quality indicated that airport cleanliness and pleasant environment are the key satisfiers whereas security check, confusing signage and poor dining offer found to be major dissatisfiers however the overall influence of these factors together in assessing the overall satisfaction is not yet studied.

Engel et al., [6] claimed that passengers attitude to a service is proportional to the strength of their beliefs about the different attributes attached with service and the weight of the attributes.

Fodness and Murray [1] had gone beyond the traditional service quality measures used in the airport industry and introduced new constructs such as function, interaction and diversion which are identified as three major areas in very board perspective; however the relationship with these constructs and overall satisfaction of passengers has not been identified.

Hansemark and Albinson [7] indicated customer satisfaction as an attitude of customers towards a service product, or a kind of emotional response to the gap between customer anticipation and customer perception in fulfilling their needs and wants however the attribute or factors that contribute significantly in generating customer overall satisfaction was not found in the literature.

Customer satisfaction is achieved by providing optimum level of services that customer expects particularly the highly- valued ones and simultaneously keep away those attributes that customers do not value. This could be ensured by constant reviewing of customer feedback and also knowing and assessing customer expectations accurately [8-11].

\section{RATIONALE OF THE STUDY}

Presently Airport service quality is assessed based on each customer interaction areas which are often considered as separate non-interactive sections, for e.g. Check-in and security functions are performed by different agencies. The airport service quality items were included under various sub headings corresponding to these areas in the ACI- ASQ survey questionnaire. Each sub headings demonstrates various interaction stages faced by passengers at the departing and arrival terminals of airports.

Industry trend shows that today airports are keen to develop facilities with the support of innovative technological advancements which simplifies passenger processing procedures. To keep up with the change in priorities of the passengers travelling through airports, it is now essential for airport operators to know in depth about the service quality facets specifically the expectations and perceptions of passengers and the key factors that influence their satisfaction which ultimately makes a better passenger experience.

\section{OBJECTIVES OF THE STUDY}

This study tries to accomplish the following objectives as stated below:

a. To explore the airport service quality dimensions from airline passenger's perspective

b. To appraise the strength of each airport service quality dimensions and its effect on overall satisfaction of passengers

\section{MATERIAL AND METHODS}

Data was collected with a standard questionnaire used by ACI-ASQ for survey among passengers. Passengers were asked to rate each item according to a 5-point scale. Passengers were located at the departure hall of various airports India. Out of 1100 passengers approached, only 957 responses were found to be completed after scrutiny of filled up questionnaires and taken for the analysis which forms the sample size for this study. It was ensured that all the passengers participated in the survey have already had air travel experience through any of the airports in India by verify them with a prerequisite question for participating in the survey. Since it was presumed that a passenger cannot respond to all the items in the questionnaire unless he/she had air travel experience.

Those factors extracted with Eigen value more than one and average variance extracted above 50 per cent were only taken for further analysis. The underlying dimensions that summaries the airport service quality dimensions were taken as a measurement model and were further verified with other statistical tests that ensures the internal consistency of items. Confirmatory Factor Analysis (CFA) was performed to validate the measurement model obtained from EFA. After verifying the measurement model, a structural equation modeling (SEM) was carried out to examine the relationship between the independent factor dimensions of airport service quality and the dependent variable in this study namely passenger satisfaction. The regression estimates of each measurement models (factor-constructs) that explain the passenger satisfaction were obtained from the SEM output text results. 
The various indicator items that describe ASQ were identified from the ACI-ASQ survey questionnaire used by various airports in India. These 33 ASQ attribute items are classified in terms of their respective functional area as given in the ACI-ASQ survey instrument which is normally rated by the passengers on a 5 point scale. The functional area and the indicative items are as given in Table-1 below.

Table-1: Indicative items for measuring ASQ based on ACI-ASQ instrument

\begin{tabular}{|c|c|}
\hline Functional Area & ASQ Indicative items \\
\hline \multirow{4}{*}{ ACCESS } & Ground transportation to /from airport \\
\hline & Availability of parking facilities \\
\hline & Value for money of parking facilities \\
\hline & Availability of baggage carts/trolleys \\
\hline \multirow[t]{3}{*}{ CHECK-IN } & Waiting time in check-in queue/line \\
\hline & Efficiency of check-in staff \\
\hline & Courtesy, helpfulness of check-in staff \\
\hline \multirow[t]{2}{*}{ PASSPORT/PERSONAL ID CONTROL } & Waiting time at passport/personal ID inspection \\
\hline & Courtesy and helpfulness of inspection staff \\
\hline \multirow[t]{4}{*}{ SECURITY } & Courtesy and helpfulness of security staff \\
\hline & Thoroughness of security inspection \\
\hline & Waiting time at security inspection \\
\hline & Feeling of being safe and secure \\
\hline \multirow[t]{4}{*}{ FINDING YOUR WAY } & Ease of finding your way through airport \\
\hline & Flight information screens \\
\hline & Walking distance inside the terminal \\
\hline & Ease of making connections with other flights \\
\hline \multirow[t]{11}{*}{ AIRPORT FACILITIES } & Courtesy, helpfulness of airport staff \\
\hline & Restaurant/eating facilities \\
\hline & Value for money of restaurants/eating facilities \\
\hline & Availability of bank /ATM facilities/money changers \\
\hline & Shopping facilities \\
\hline & Value for money for shopping facilities \\
\hline & Internet access/Wi-Fi \\
\hline & Business/ Executive lounges \\
\hline & Availability of washrooms/toilets \\
\hline & Cleanliness of washrooms/toilets \\
\hline & Comfort of waiting /gate areas \\
\hline \multirow[t]{2}{*}{ AIRPORT ENVIRONMENT } & Cleanliness of airport terminal \\
\hline & Ambience of the airport \\
\hline \multirow[t]{3}{*}{ ARRIVAL SERVICES } & Passport/Personal ID inspection \\
\hline & Speed of baggage delivery service \\
\hline & Customs inspection \\
\hline
\end{tabular}

Exploratory Factor Analysis (EFA) was performed with the data obtained as per the ratings provided by passengers based on their experience at the airport. Adequacy of the sample was examined in terms of its validity and reliability of the data.

\section{RESULTS AND DISCUSSION Exploratory Factor Analysis}

Exploratory Factor Analysis (EFA) was performed primarily for simple data reduction and understanding latent constructs. Hence the use of EFA is more pragmatic than theoretical and the intention was to consider a reasonably large number of variables and then reduce them to a smaller, more manageable number while retaining as much of the original variance as possible.

Exploratory Factor Analysis was performed with Principle component analysis method. Table-2 provides the details of factor loadings with total variance explained. 
Joemon Pappachan; Saudi J Bus Manag Stud, Jan., 2020; 5(1): 10-18

Table-2: Total Variance Explained

\begin{tabular}{|c|c|c|c|c|c|c|c|c|c|}
\hline \multirow[t]{2}{*}{ Component } & \multicolumn{3}{|c|}{ Initial Eigen values } & \multicolumn{3}{|c|}{$\begin{array}{l}\text { Extraction Sums of Squared } \\
\text { Loadings }\end{array}$} & \multicolumn{3}{|c|}{$\begin{array}{l}\text { Rotation Sums of Squared } \\
\text { Loadings }\end{array}$} \\
\hline & Total & $\begin{array}{l}\% \text { of } \\
\text { Variance }\end{array}$ & $\begin{array}{l}\text { Cumulative } \\
\%\end{array}$ & Total & $\begin{array}{l}\% \text { of } \\
\text { Variance }\end{array}$ & $\begin{array}{l}\text { Cumulative } \\
\%\end{array}$ & Total & $\begin{array}{l}\% \text { of } \\
\text { Variance }\end{array}$ & $\begin{array}{l}\text { Cumulative } \\
\%\end{array}$ \\
\hline 1 & 16.128 & 48.873 & 48.873 & 16.128 & 48.873 & 48.873 & 8.068 & 24.449 & 24.449 \\
\hline 2 & 2.774 & 8.406 & 57.279 & 2.774 & 8.406 & 57.279 & 5.779 & 17.512 & 41.961 \\
\hline 3 & 1.544 & 4.678 & 61.957 & 1.544 & 4.678 & 61.957 & 3.559 & 10.785 & 52.746 \\
\hline 4 & 1.358 & 4.117 & 66.074 & 1.358 & 4.117 & 66.074 & 3.178 & 9.629 & 62.375 \\
\hline 5 & 1.275 & 3.864 & 69.937 & 1.275 & 3.864 & 69.937 & 2.496 & 7.562 & 69.937 \\
\hline 6 & .945 & 2.862 & 72.799 & & & & & & \\
\hline 7 & .849 & 2.572 & 75.371 & & & & & & \\
\hline 8 & .810 & 2.455 & 77.826 & & & & & & \\
\hline 9 & .667 & 2.021 & 79.847 & & & & & & \\
\hline 10 & .604 & 1.831 & 81.678 & & & & & & \\
\hline 11 & .552 & 1.674 & 83.352 & & & & & & \\
\hline 12 & .485 & 1.469 & 84.821 & & & & & & \\
\hline
\end{tabular}

EFA was performed with the data obtained as per the ratings provided by passengers based on their experience at the airport. Five components were obtained with varimax rotation and explained about 70 percent of the variance. Table- 3 provides the details:

Table-3: Rotated Component Matrix

\begin{tabular}{|c|c|c|c|c|c|c|}
\hline \multirow[t]{2}{*}{ Factor item code } & \multirow[t]{2}{*}{ Description of items } & \multicolumn{5}{|c|}{ Component } \\
\hline & & 1 & 2 & 3 & 4 & 5 \\
\hline $\mathrm{C} 2$ & Efficiency of check-in staff & .813 & .087 & .217 & .076 & .119 \\
\hline $\mathrm{C} 3$ & Courtesy of check-in staff & .780 & .125 & .222 & .044 & .137 \\
\hline S1 & Courtesy of security staff & .776 & .265 & .120 & .247 & .155 \\
\hline P2 & Courtesy of inspection staff & .765 & .195 & .020 & .233 & .210 \\
\hline $\mathrm{C} 1$ & Check -in queue & .749 & .138 & .219 & .153 & .110 \\
\hline S3 & Waiting time for security check & .739 & .310 & .172 & .266 & .108 \\
\hline S2 & Quality of security inspection & .732 & .259 & .169 & .246 & .094 \\
\hline P1 & Waiting time for passport inspection & .731 & .205 & .046 & .229 & .195 \\
\hline S4 & Feeling of safe and secure & .700 & .249 & .219 & .255 & .117 \\
\hline N3 & Terminal walking distance & .586 & .380 & .145 & .284 & .079 \\
\hline N1 & Navigational aids & .578 & .309 & .212 & .305 & .034 \\
\hline $\mathrm{N} 2$ & Flight info screen & .575 & .407 & .136 & .274 & .045 \\
\hline $\mathrm{N} 4$ & Flight connection easiness & .533 & .393 & .142 & .291 & .125 \\
\hline A1 & Courtesy of airport staff & .518 & .475 & .200 & .184 & .136 \\
\hline A5 & Shopping facilities & .206 & .796 & .266 & .116 & .145 \\
\hline A6 & Value for money for shopping & .197 & .795 & .212 & .135 & .184 \\
\hline A4 & Bank ATM facilities & .183 & .735 & .203 & .195 & .144 \\
\hline A2 & Eating facilities & .352 & .733 & .154 & .164 & .089 \\
\hline A3 & Value for money for eating facilities & .290 & .731 & .054 & .190 & .145 \\
\hline A7 & Internet - wifi facilities & .250 & .662 & .277 & .106 & .205 \\
\hline A8 & Business lounges & .189 & .623 & .354 & .053 & .142 \\
\hline E1 & Terminal cleanliness & .164 & .134 & .777 & .208 & .127 \\
\hline E2 & Airport ambience & .167 & .191 & .761 & .139 & .146 \\
\hline A10 & Cleanliness of washroom & .256 & .401 & .691 & .101 & .169 \\
\hline A11 & Comfort at waiting gate areas & .256 & .376 & .685 & .106 & .176 \\
\hline A9 & Washroom - availability of toilet facilities & .267 & .464 & .639 & .092 & .159 \\
\hline AS2 & Parking facilities & .327 & .167 & .183 & .815 & .116 \\
\hline AS3 & Parking value & .339 & .234 & .095 & .750 & .170 \\
\hline AS1 & Ground transportation to $\&$ fro from airport & .384 & .191 & .190 & .694 & .127 \\
\hline AS4 & Trolley availability & .463 & .180 & .186 & .645 & .090 \\
\hline AR3 & Customs inspection quality & .200 & .197 & .147 & .086 & .805 \\
\hline AR2 & Baggage - delivery speed & .167 & .234 & .218 & .169 & .798 \\
\hline AR1 & Arrival - passport \& visa inspection & .234 & .229 & .201 & .124 & .791 \\
\hline
\end{tabular}


Joemon Pappachan; Saudi J Bus Manag Stud, Jan., 2020; 5(1): 10-18

Following ASQ dimensions were arrived based on the results obtained through EFA. Only those item with factor loading value greater than 0.6 were considered as an indicator item for each dimension. It was noticed that the new ASQ dimensions explored through factor analysis was more or less similar to the ASQ areas identified in the ACI -ASQ survey instrument, however the number of dimensions have further reduced and all factors related to people-counter interactions were converged together and formed into one single dimension. Five ASQ dimensions explored based on passenger perspective and the corresponding indicative items are shown in Table-4:

Table-4: ASQ dimensions and indicative items

\begin{tabular}{|c|c|c|}
\hline Item code & Indicative Item - Description & ASQ Dimension \\
\hline $\mathrm{C} 2$ & Efficiency of check-in staff & \multirow[t]{9}{*}{ People Interactions } \\
\hline $\mathrm{C} 3$ & Courtesy of check-in staff & \\
\hline S1 & Courtesy of security staff & \\
\hline $\mathrm{P} 2$ & Courtesy of inspection staff & \\
\hline $\mathrm{C} 1$ & Check -in queue & \\
\hline S3 & Waiting time for security check & \\
\hline $\mathrm{S} 2$ & Quality of security inspection & \\
\hline $\mathrm{P} 1$ & Waiting time for passport inspection & \\
\hline S4 & Feeling of safe and secure & \\
\hline A5 & Shopping facilities & \multirow[t]{7}{*}{ Airport facilities -Consumption value } \\
\hline A6 & Value for money for shopping & \\
\hline A4 & Bank ATM facilities & \\
\hline $\mathrm{A} 2$ & Eating facilities & \\
\hline A3 & Value for money for eating facilities & \\
\hline A7 & Internet - wifi facilities & \\
\hline A8 & Business lounges & \\
\hline E1 & Terminal cleanliness & \multirow[t]{5}{*}{ Hygiene - Comfort factors } \\
\hline E2 & Airport ambience & \\
\hline A10 & Cleanliness of washroom & \\
\hline A11 & Comfort at waiting gate areas & \\
\hline A9 & Washroom - availability of toilet facilities & \\
\hline $\mathrm{AS} 2$ & Parking facilities & \multirow[t]{4}{*}{ Access - Entry factors } \\
\hline AS3 & Parking value & \\
\hline AS1 & Ground transportation to $\&$ fro from airport & \\
\hline AS4 & Trolley availability & \\
\hline AR3 & Customs inspection quality & \multirow[t]{3}{*}{ Arrival Services } \\
\hline AR2 & Baggage - delivery speed & \\
\hline AR1 & Arrival - passport \& visa inspection & \\
\hline
\end{tabular}

\section{Internal consistency of the factor items}

Internal consistency of each factor item was checked using SPSS - reliability analysis scale items. Cronbach Alpha values obtained for all five factor dimensions are provided in Table-5. Since all the values obtained are above the acceptable threshold value of 0.7 [12], internal consistency (reliability) of items are found to be valid.

Table-5: Reliability of the factor items

\begin{tabular}{|l|l|l|}
\hline ASQ Dimensions & No. of Items & Cronbach Alpha value \\
\hline People Interactions & 9 & 0.946 \\
\hline Airport facilities -Consumption value & 7 & 0.921 \\
\hline Hygiene - Comfort factors & 5 & 0.894 \\
\hline Access - Entry factors & 4 & 0.896 \\
\hline Arrival Services & 3 & 0.853 \\
\hline
\end{tabular}

\section{Test of sampling adequacy}

To check the adequacy of the sample size used for factor analysis, Kaiser- Meyer- Oklin (KMO) and Bartlett's Test is used, results of which indicate significant values. KMO value 0.947 (see Table-6) higher than the threshold value of 0.6 , indicate good measure of sampling adequacy. 
Table-6: KMO and Bartlett's Test

\begin{tabular}{|l|l|l|}
\hline Kaiser-Meyer-Olkin Measure of Sampling Adequacy. & .947 \\
\hline \multirow{3}{*}{ Bartlett's Test of Sphericity } & Approx. Chi-Square & 28467.33 \\
\cline { 2 - 3 } & df & 528 \\
\cline { 2 - 3 } & Sig. & .000 \\
\hline
\end{tabular}

\section{Confirmatory Factor Analysis}

Confirmatory Factor Analysis (CFA) provides better control for assessing uni-dimensionality than Exploratory Factor Analysis and is more in proportion to the overall process of construct validation. CFA provide evidences regarding confirmation of the measurement model taken in this study with five dimensions explored by EFA method. CFA can provide clarity on indicator items which are replicated in a given set of factor dimensions and its interrelationships are assessed with the goodness of fit indices. Fig-1 explains the hypothesized model followed by summary of model fit indices. It is found that the five underlying dimensions of airport service quality are statistically valid.

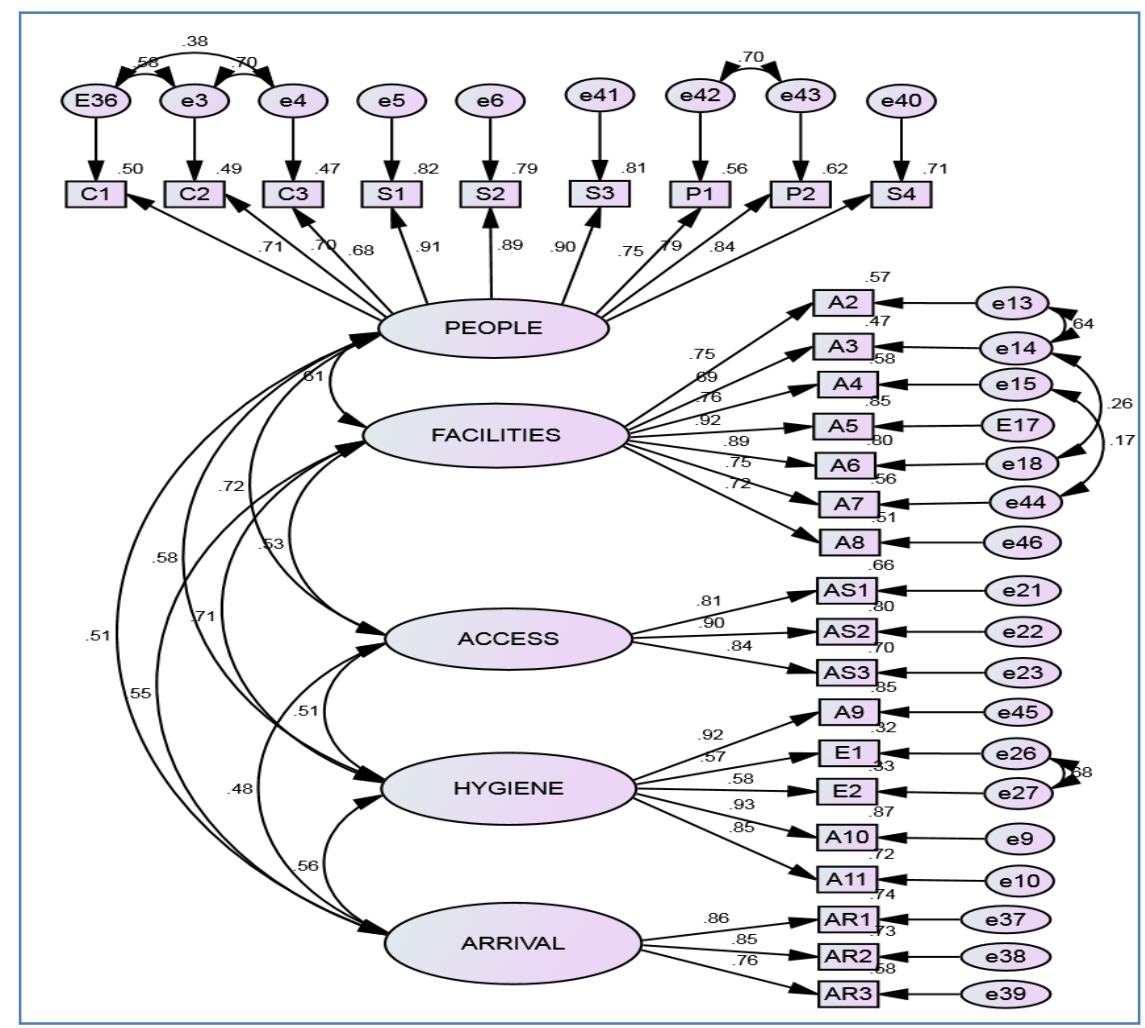

Fig-1: ASQ Dimensions: CFA - measurement model

Model indices which are not very sensitive to sample size like CFI, TLI, RMSEA are showing good fit results. It can be inferred that these five factors with reflecting indicators shows best fit the measurement model confirming Airport Service Quality. Table-7 provides the various model fit indices.

Table-7: Measurement model fit indices

\begin{tabular}{|c|c|c|c|c|c|}
\hline Model & NPAR & CMIN & DF & $\mathbf{P}$ & CMIN/DF \\
\hline Default model & 72 & 1462.215 & 306 & .000 & 4.778 \\
\hline Model & RMR & GFI & AGFI & PGFI & \\
\hline Default model & .024 & .899 & .876 & .728 & \\
\hline
\end{tabular}

\begin{tabular}{|c|l|l|l|l|l|l|}
\hline Model & RMSEA & LO 90 & HI 90 & PCLOSE \\
\hline Default model & .063 & .060 & .066 & .000 \\
\hline Model & $\begin{array}{l}\text { NFI } \\
\text { Delta1 }\end{array}$ & $\begin{array}{l}\text { RFI } \\
\text { rho1 }\end{array}$ & $\begin{array}{l}\text { IFI } \\
\text { Delta2 }\end{array}$ & $\begin{array}{l}\text { TLI } \\
\text { rho2 }\end{array}$ & CFI \\
\hline Default model & .938 & .929 & .950 & .943 & .950 \\
\hline
\end{tabular}


Joemon Pappachan; Saudi J Bus Manag Stud, Jan., 2020; 5(1): 10-18

CMIN/DF is called as the minimum discrepancy which is obtained as 4.77. Wheaton [13] suggested that if the minimum discrepancy is less than 5 the model is reasonably fit. If the fit indices values for CFI, RFI, NFI are greater than 0.9 and if RMSEA value is less than 0.08, it indicates model is fit and accepted as per the studies conducted by Bentler and Bonett [14].
ASQ measurement model: Regression Estimates ASQ dimensions

Table- 8 shows the details of variances of all ASQ dimensions, regression estimates and the level of significance at $95 \%$ confidence level. It has been observed from the default model that the regression weights obtained for all the five ASQ dimensions are significant.

Table-8: Regression estimates for ASQ dimensions

\begin{tabular}{|l|l|l|l|l|l|}
\hline ASQ dimensions & Estimate & S.E. & C.R. & P & Label \\
\hline PEOPLE & .309 & .017 & 18.029 & $* * *$ & \\
\hline FACILITIES & .372 & .028 & 13.459 & $* * *$ & \\
\hline ACCESS & .323 & .022 & 14.676 & $* * *$ & \\
\hline HYGIENE & .066 & .007 & 9.346 & $* * *$ & \\
\hline ARRIVAL & .155 & .010 & 15.652 & $* * *$ & \\
\hline
\end{tabular}

Though all the dimensions are significant, it was found that the Hygiene dimension has least critical ratio (C.R.) value when compared with other dimensions. However the influence of all dimensions on over all satisfaction of passengers is yet to be ascertained.
Effect of airport service quality dimensions on passenger overall satisfaction

Though the measurement model for ASQ dimensions were validated by Confirmatory Factor Analysis, it was necessary to appraise the effect of these dimensions on passengers' overall satisfaction. The relationship between the variables is identified with structural equation modeling (SEM) by using AMOS. The model identified is plotted in Fig-2.

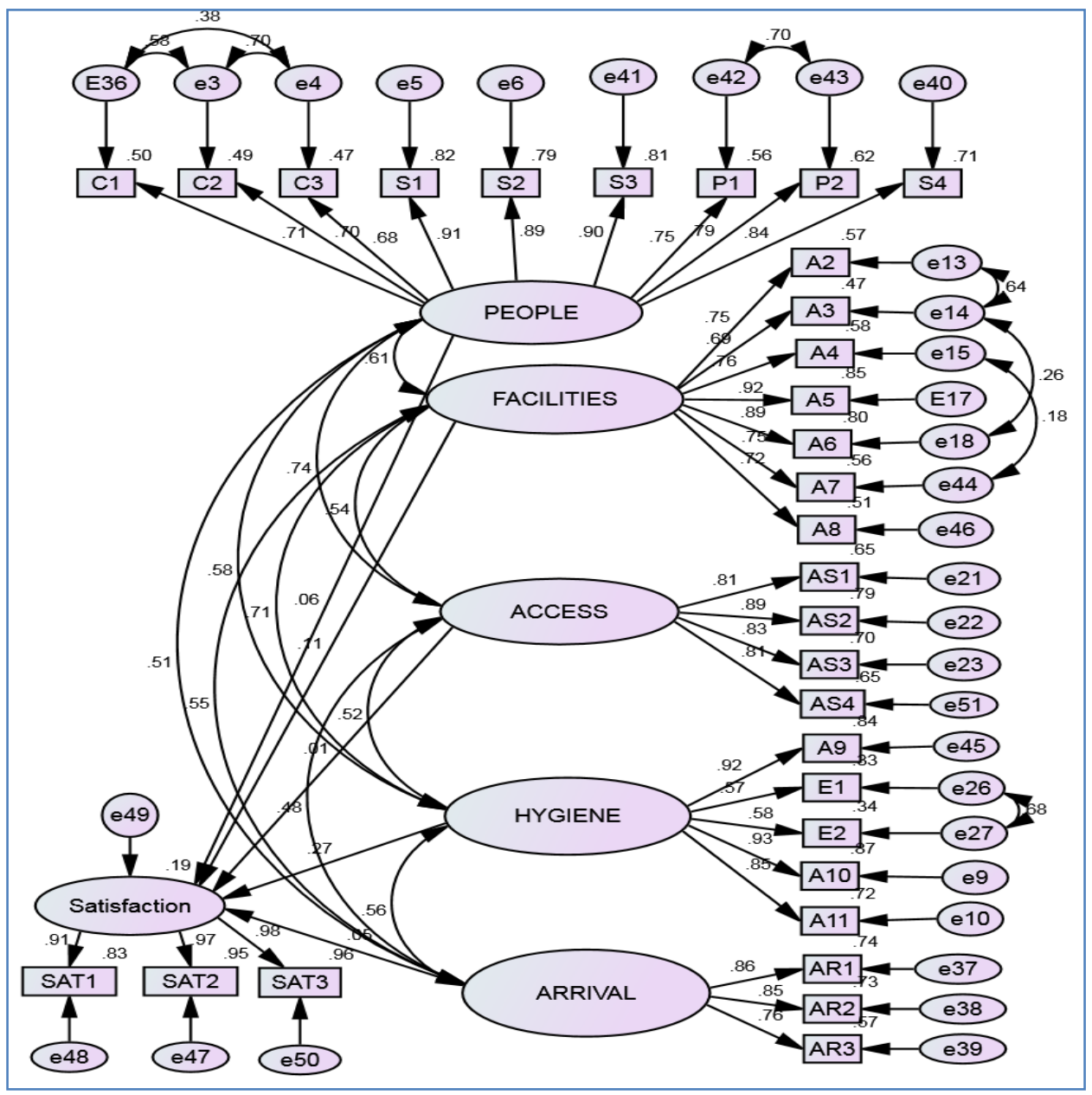

Fig-2: Effect of ASQ dimensions on overall passenger satisfaction 
Joemon Pappachan; Saudi J Bus Manag Stud, Jan., 2020; 5(1): 10-18

The model fit summary with all relevant fit indices is provided in Table-9. It was noticed that all the fit indices values are found to be within the acceptable limits and the model was accepted.

Table-9: Summary of model fit indices of Passenger satisfaction model

\begin{tabular}{|c|c|c|c|c|c|c|}
\hline \multicolumn{7}{|c|}{ CMIN } \\
\hline Model & NPAR & \multicolumn{2}{|c|}{ CMIN } & $\mathrm{DF}$ & $\mathrm{P}$ & CMIN/DF \\
\hline Default model & 85 & \multicolumn{2}{|c|}{1820.664} & 411 & .000 & 4.430 \\
\hline \multicolumn{7}{|c|}{ RMR, GFI } \\
\hline \multicolumn{2}{|l|}{ Model } & \multicolumn{2}{|c|}{ RMR } & GFI & AGFI & PGFI \\
\hline \multicolumn{2}{|c|}{ Default model } & \multicolumn{2}{|c|}{.022} & \begin{tabular}{|l|l|}
.893 \\
\end{tabular} & .870 & .740 \\
\hline \multicolumn{7}{|c|}{ Baseline Comparisons } \\
\hline \multicolumn{2}{|l|}{ Model } & \begin{tabular}{|l|} 
NFI \\
Delta1
\end{tabular} & $\begin{array}{l}\text { RFI } \\
\text { rho1 }\end{array}$ & \begin{tabular}{|l} 
IFI \\
Delta2
\end{tabular} & $\begin{array}{l}\text { TLI } \\
\text { rho2 }\end{array}$ & CFI \\
\hline \multicolumn{2}{|c|}{ Default model } & .937 & .929 & .950 & .944 & .950 \\
\hline \multicolumn{7}{|c|}{ RMSEA } \\
\hline \multicolumn{2}{|l|}{ Model } & \multicolumn{2}{|c|}{ RMSEA } & LO 90 & HI 90 & PCLOSE \\
\hline Default model & & .060 & & .057 & .063 & .000 \\
\hline Independence & nodel & .253 & & .250 & .255 & .000 \\
\hline & & HO & ELT & ER & & \\
\hline Model & & & $\begin{array}{l}\mathrm{HO} \\
.05\end{array}$ & ELTER & $\begin{array}{l}\text { HOEL } \\
.01\end{array}$ & TER \\
\hline Default & nodel & & 242 & & 253 & \\
\hline Indepen & ence $\mathrm{r}$ & odel & 18 & & 18 & \\
\hline
\end{tabular}

The regression weights of ASQ dimensions on passenger satisfaction were analyzed and the results obtained are plotted in Table-10.

Table-10: Regression weights: ASQ -Satisfaction model

\begin{tabular}{|l|l|l|l|l|l|l|l|}
\hline \multicolumn{2}{|l|}{ Effect of ASQ variables } & Estimate & S.E. & C.R. & P & Label \\
\hline Satisfaction & $<---$ & PEOPLE & .046 & .038 & 1.220 & .223 & \\
\hline Satisfaction & $<---$ & FACILITIES & .071 & .033 & 2.134 & .033 & \\
\hline Satisfaction & $<---$ & ACCESS & .008 & .036 & .214 & .830 & \\
\hline Satisfaction & $<---$ & HYGIENE & .406 & .078 & 5.204 & $* * *$ & \\
\hline Satisfaction & $<---$ & ARRIVAL & .049 & .043 & 1.134 & .257 & \\
\hline
\end{tabular}

The regression weights and the $\mathrm{P}$ values with regard to the relationship between ASQ dimensions on passengers overall satisfaction indicates that only Hygiene dimension has got significant effect on passenger satisfaction. This is in contrast with the regression estimate values obtained for Hygiene dimension in the ASQ measurement model. Airport facilities have also got reasonable influence on passenger satisfaction. This could be attributed by the fact that passengers attribute satisfaction with respect to pure airport specific factors such as facilities provided by airport directly which involve two dimensions namely 'hygiene' and 'airport facilities'. Whereas dimensions like 'access', 'arrival' and 'people' are those dimensions not fully under the control of airports as they are provided in the airport by various airline and govt. agencies. Even though all the five factor dimensions were found to be valid in the measurement model, only two dimensions namely, Hygiene and Airport facilities have got effect on overall passenger satisfaction.

This result put forward managerial implications for airport operators as passengers are satisfied mainly by airport specific factors and any improvement in airport hygiene and facilities would result in positive effect on both ASQ and Overall satisfaction of airline passengers.

\section{CONCLUSION}

Five ASQ dimensions are explored in this study as against to the conventional method of setting apart ASQ areas functional-wise which were identified from all contact points in the functional flow of passengers. The ASQ dimensions identified in this study are all well set to explain Airport Service Quality from a passengers' perspective rather than airport functional or passenger processing perspective. One of the major finding of this study is the identification of peculiar effect of hygiene factor dimension on the overall satisfaction of passengers. Hygiene to be specifically 'hygiene and comfort' factor was little dormant when compared with other ASQ dimensions in the measurement model of Airport Service Quality. While testing the effect of all five dimensions of ASQ on passenger satisfaction by using a structured equation model the Hygiene dimension was overridden above all other dimensions in depicting passenger satisfaction. 


\section{REFERENCES}

1. Fodness, D., \& Murray, B. (2007). Passengers' expectations of airport service quality. Journal of Services Marketing, 21(7):492-506.

2. Park, J. W., Robertson, R., \& Wu, C. L. (2004). The effect of airline service quality on passengers' behavioral intentions: a Korean case study. Journal of Air Transport Management, 10:435439.

3. Chen, F. Y., \& Chang, Y. H. (2005). Examining airline service quality from a process perspective. Journal of Air Transport Management, 11(2):7987.

4. Gursoy, D., Chen, M. H., \& Kim, H. Y. (2005). The US airlines relative positioning based on attributes of service quality. Tourism Management, 26(1):57-67.

5. Bogicevic, V., Yang, W., Bilgihan, A., \& Bujisic, M. (2013). Airport service quality drivers of passenger satisfaction, Tourism Review, 68(4):318.

6. Engel, J. F., Blackwell, R. D., \& Miniard, P. W. (1995). Consumer Behavior, eighth ed. The Dryden Press, Forth Worth, TX.
7. Hansemark, O. C., \& Albinson, M. (2004). Customer satisfaction and retention: the experiences of individual with employees. Managing Service Quality, 14(1):40-57.

8. Evelyn, J. J., \& De Carlo, N. J. (1992). Customer focus helps utility see the light. The Journal of Business Strategy, 8-12

9. Miller, T. O. (1992). A customer's definition of quality", The Journal of Business Strategy, 4-7.

10. Peters, T. J., \& Austin, N. (1985). A Passion for Excellence, Random House, New York, NY.

11. Sonnenberg, F. K. (1991). Marketing to Win, Harper and Row, New York, NY.

12. Nunnally, J. C. (1978). Psychometric Theory, New York: McGraw- Hill.

13. Wheaton, B. (1977). Assessment of fit in over identified models with latent variables. Sociological Methods and Research, 16:118-154.

14. Bentler, P. M., \& Bonett, D. G., (1980). Significance tests and goodness of fit in the analysis of Covariance structures, Psychological Bulletin, 88:588-606. 